Article

\title{
Inclusive Financial Development and Multidimensional Poverty Reduction: An Empirical Assessment from Rural China
}

\author{
Yanlin Yang and Chenyu Fu * \\ Center for Economic Development Research and Center of Population, Resource \& Environmental Economics \\ Research, School of Economics and Management, Wuhan University, Wuhan 430072, China; yyl7772@163.com \\ * Correspondence: 2016101050047@whu.edu.cn; Tel.: +86-138-8608-0693
}

Received: 13 December 2018; Accepted: 11 March 2019; Published: 29 March 2019

check for updates

\begin{abstract}
Inclusive finance is often considered to be a critical element that makes growth inclusive, as access to finance can enable the poor to lift themselves from income poverty. However, can it play such a role when the poor are in multidimensional poverty? Why does financial exclusion and poverty still exist in countries with vigorous development of inclusive finance? We build an evolutionary game model to analyze the equilibrium strategies of inclusive financial institutions and the poor in poverty reduction activities to find the answers. As there is a high incidence of poverty and serious financial exclusion in rural areas of China, we test the poverty reduction effectiveness of inclusive financial development on the poor with different labor capacity in rural China from 2010 to 2016 based on survey data of China Family Panel Studies and relevant statistics collected from 21 provinces. Our study finds there are differences in poverty alleviation effects of inclusive financial development among the poor with different labor capacities; if financial institutions target the service precisely to the working-age population in rural areas, they will achieve the dual goals of maintaining institutional sustainable development and alleviating poverty; And the development of inclusive finance in aspects of permeability, usability, and utility can significantly reduce multidimensional poverty. Therefore, to further improve the multidimensional poverty reduction performance and stimulate the endogenous motivation of the poor, it is necessary to strengthen the support for financial resources served to the working-age population, and to improve the development of rural inclusive finance in aspects of quality and affordability.
\end{abstract}

Keywords: inclusive finance; multidimensional poverty; targeted poverty reduction; evolutionary game; China

\section{Introduction}

To achieve the Millennium Development Goals on ending extreme poverty and hunger, the United Nations explicitly proposed to develop an inclusive financial system in 2005. The experience of Bangladesh's Grameen Bank, Bolivia's Banco Solidario, Indonesia's Bank Rakyat, rural Indonesia's Bank Kredit Desa and Latin America's Village Bank have confirmed that inclusive finance is an effective tool for achieving poverty alleviation and sustainable development [1]. In fact, poverty entails more than a lack of income and productive resources to ensure sustainable livelihoods. Its manifestations include hunger and malnutrition, limited access to education and other basic services, social discrimination and exclusion, as well as the lack of participation in insurance and decision-making. As multidimensional poverty is treated as matters of degree determined in terms of the individual's position in the distribution of some aspects of their living conditions and basic feasible capacity [2], we should use a new multidimensional method to measure poverty and analyze 
whether inclusive financial development can effectively alleviate multidimensional poverty, which helps countries gauge program effectiveness and guide their development strategy in a rapidly changing economic environment.

China is a developing country with a large number of rural poor. Ending poverty is also a major task for China to achieve sustainable development. Under the rural vitalization strategy, issues relating to agriculture, rural areas, and rural people are fundamental to China as they directly concern a country's stability and people's wellbeing. Therefore, the Chinese government has always adhered to the development-oriented poverty alleviation strategy and rural vitalization strategy. "Decision of the CPC Central Committee and the State Council on Winning the Fight against Poverty" was put forward, and the goal of poverty alleviation is to ensure that the rural poor will not worry about food and clothing anymore, and they will have the basic rights of compulsory education, basic medical treatment, and housing, in accordance with the policy of the United Nations on multidimensional poverty alleviation. Under the development-oriented poverty alleviation strategy, the method of poverty alleviation has shifted from "blood transfusion" to "blood creation"-poor people should depend on their own hard work to lift themselves out of poverty and get richer. However, the rural poor do not have enough money to strengthen nutrition, to improve welfare, or to develop production; worse, they are also excluded by formal financial sectors and cannot obtain the financial services they need. These factors lead to a vicious cycle [3]. In this case, inclusive finance can play a critical role in poverty alleviation, as increasing the rural poor's access to financial services at an affordable cost and with equal chance [4]. Access to a well-functioning financial system empowers the rural poor, can help them improve their livelihoods, protect them against economic shocks and provide funds for creating jobs or learning; in this way, developing inclusive finance targeted towards the poor in rural areas has become a key financial policy for China to promote inclusive economic growth.

However, inclusive finance does not alleviate poverty in the form of social assistance; it generally only addresses poverty issues with economic development prospects to maintain the sustainable development of its institutions, so its clients should have the potential for development and have the ability to repay the capital and interest [5]. Among the poor in rural areas, the group with the strongest labor capacity and development potential is the poor working-age population. They are also the key group for realizing the goal of "a people to work pull a family out of poverty". If a rural poor working-age population can improve its multidimensional poverty through access to the needed financial resources, the dual effect of promoting inclusive financial development and raising the level of human capital in rural areas can be achieved. As financial resources and labor resources are two essential factors for economic growth, it is also an important method for promoting the sustainable development of local economy [6]. Therefore, in the context of targeted poverty reduction and alleviation, can the development of inclusive finance achieve the goal of sustaining institutional sustainable development and achieving poverty alleviation? Are there any different poverty alleviation effects of inclusive financial development among the poor with different labor capacities? To better achieve poverty reduction targets, what is the developing direction of inclusive finance?

As there is a high incidence of poverty and serious financial exclusion in rural areas of China [7], we specialize in poverty alleviation effects of rural inclusive financial development under the rural vitalization strategy. Based on survey data of China Family Panel Studies (CFPS) and relevant statistics collected from 21 provinces, we measure poverty in a multidimensional method, studying the poverty reduction effects of rural inclusive financial development among the poor with different labor capacities, and analyze the difference of poverty reduction effects in different aspects of inclusive finance. Innovations are as follows: firstly, we analyzed the equilibrium strategies of inclusive financial institutions and the poor in poverty reduction activities from the perspective of the evolutionary game. Secondly, we analyzed the poverty alleviation effects of rural inclusive financial development on the rural poor with different labor capacities.

The remainder of this article is organized as follows. Section 2 reviews related literature, while Section 3 builds an evolutionary game model to analyze the action strategies of inclusive financial 
institutions and the poor in poverty reduction activities. Section 4 presents approaches to rural inclusive financial development measurement and multidimensional poverty measurement, and constructs the metrological model. Section 5 analyzes the empirical results, and Section 6 provides a conclusion and suggestions.

\section{Literature Review}

A lot of literature has studied the relationship between inclusive financial development and poverty alleviation. Some studies argue that (rural) inclusive financial development provides the poor with access to credit, savings, and other financial products and services, so that they can enjoy financial functions for poverty reduction directly. For instance, Kabeer found that microfinancial development in South Asia can and does make vital contributions to the economic productivity and social welfare of poor women and their households by financial empowerment [8]. Park and Mercado found that access to finance can enable the poor to make longer-term consumption and investment decisions, participate in productive activities, and cope with unexpected short-term shocks, which helps to alleviate poverty and income inequality [9]. Corrado and Corrado suggest that access to credit is a key instrument to access other primary services and social activities, so inclusive finance empowers the poor to exploit better economic and social opportunities and enable them to participate in productive economic activities [4]. He and Kong found that inclusive finance can increase poor farmers' income by the mechanism of releasing rural credit constraints, which helps them to improve the risk resistance ability and reduces the cost of obtaining financial services [10]. Some studies hold that (rural) inclusive financial development can further enhance the promotion of economic development and the optimization of income distribution in breadth, and indirectly achieve the results of income growth and poverty alleviation through the "trickle-down effect". Beck et al., Su and Liao, Ding, Cui and Sun, Chen and Zhang have verified this mechanism from the positive side by theoretical and empirical studies [11-15]. Leyshon and Thrift, Kempson and Whyley, Liu have verified this conclusion from the opposite side, finding that restraining financial development would increase the disparity of economic development and income distribution between regions, thus exacerbating the imbalance of regional economic development and resulting in more general social exclusion, which is not conductive to poverty alleviation [16-18]. Furthermore, some studies suggest that although inclusive finance can alleviate poverty and promote economic growth, it has different poverty reduction effects among different poor groups, the main beneficiaries being slightly poor families, and the effect of poverty reduction on extremely poor families being not significant [19]. Khaki and Sangmi found that access to finance can alleviate poverty, but funds are allocated to non-poor sections rather than absolute poor [20].Zhu and Wang showed that inclusive financial development can effectively alleviate poverty by promoting economic growth, but this effect is heterogeneous for different income groups, that is the benefit of poverty reduction and income increase of high-income rural poor is greater than that of low-income rural poor [21].

The literature above has studied the relationship between inclusive finance and poverty reduction from the point of view of different mechanisms, but ignores the premise that inclusive financial institutions are willing to provide financial products and services to the poor. Why does financial exclusion and poverty still exist in countries with vigorous development of inclusive finance? It maybe relates to the game between inclusive financial institutions and the poor. Based on the game model, some studies analyze the evolution process of cooperation between financial institutions and the poor. For example, Kong and $\mathrm{Li}$ deem that credit default leads to financial exclusion, and trust promotes cooperation [22]; Wang and Wang suggest that a bank's lending decision mainly depends on the possibility of farmers' repayment [23]. However, the poor need financial resources to enhance their production development ability to get out of poverty. Without considering malicious credit default, their repayment ability ultimately depends on the results of production development, which in turn depends on their labor ability. Therefore, there may be differences in poverty reduction between the working-age population and the non-working-age population. 
In addition, the definition of poverty in current research is mainly limited to low income levels, and the effect of poverty alleviation is mainly judged by the income growth among all people. Moreover, the existing literature has not studied the poverty reduction effects of inclusive finance on the poor with different labor capacity, so the precision analysis of financial development for poverty alleviation is not enough. Based on this, an evolutionary game model is built to analyze the equilibrium strategies of inclusive financial institutions and the poor in poverty reduction activities, and we study the relationship between inclusive financial development and multidimensional poverty alleviation in rural areas of China.

\section{An Evolutionary Game Model}

As absolute poverty develops to relative poverty and social exclusion, it is more realistic to use multidimensional poverty to identify the poor. Multidimensional poverty mainly refers to the deficiency or deprivation of people's basic feasible capacity in many aspects, such as low income, ill health, inadequate education, lack of insurance, unemployment, and so on. Financial products and services help to enhance the self-development ability of the poor, so they need access to financial resources to alleviate poverty. However, the essence of inclusive finance is still finance, which is a commercial economic activity, and always refuses to provide products and services to the poor, especially the multidimensional poor, for the purposes of maintaining sustainable development. The poor have no mechanism to be lifted out of poverty. Therefore, financial institutions and the poor are stakeholders, and there is a game between them.

Suppose financial institutions and the poor are the two main players in the game of poverty reduction, and are both bounded rationality and limited information. To achieve the goal of poverty reduction, the poor need to obtain financial loans to carry out business activities. As a result, the poor have two strategies-one is to apply for loans, and the other is not to apply for loans. Although financial loans can help reduce multidimensional poverty, the poor may not be able to repay, which will affect the sustainable development of inclusive financial institutions. Therefore, financial institutions also have two strategies, accordingly-one is to provide loans and the other is not to provide loans. Suppose the probability of financial institutions providing loans is $\mathrm{x}$ and the probability of the poor applying for loans is $y$, then the probability of financial institutions not to providing loans is $1-x$, and the probability of the poor not to applying for loans is $1-y$. In addition, it is assumed that the loan amount is $L$, the interest rate is $r$, the investment rate of the loan is $\beta$, the transaction cost ratio of financial institutions providing loans is $c_{1}$, and the transaction cost ratio of the poor applying for loans is $c_{2}$, the success rate of developing production and management for the poor people is $k$. Under the condition that the poor apply for a loan, if the financial institutions provide the loan, then the return of the financial institution is $\mathrm{Lr}-\mathrm{Lc} c_{1}$, the return of the poor is $\mathrm{k}\left[\mathrm{L}(\beta-\mathrm{r})-\mathrm{Lc}_{2}\right]+(1-\mathrm{k})\left(-\mathrm{Lc}_{2}\right)$, if the financial institutions not to provide the loan, then the return of the financial institution is 0 , the return of the poor is $\mathrm{k}\left(-\mathrm{L} \beta-\mathrm{Lc}_{2}\right)+(1-\mathrm{k})\left(-\mathrm{Lc}_{2}\right)$. Under the condition that the poor not apply for a loan, if the financial institutions provide the loan, then the return of the financial institution is $-\mathrm{Lc}_{1}$, the return of the poor is $-\mathrm{kL} \beta$, if the financial institutions not to provide the loan, then the return of the financial institution is 0 , the return of the poor is $-\mathrm{kL} \beta$. The return matrix for financial institutions and the poor is shown in Table 1.

Table 1. The return matrix for financial institutions and the poor.

\begin{tabular}{lccc}
\hline & & \multicolumn{2}{c}{ The Poor } \\
\hline \multirow{2}{*}{ Financial institutions } & provide & $\mathrm{Lpply}$ & Not to Apply \\
\cline { 2 - 4 } & not to provide & $0,-\mathrm{LL} \beta-\mathrm{Lc} \beta-\mathrm{Lr}-\mathrm{Lc}_{2}$ & $-\mathrm{Lc} c_{1},-\mathrm{kL} \beta$ \\
\hline
\end{tabular}


As a result, the expected return on providing loans of financial institutions is $\pi_{11}=\mathrm{y}\left(\mathrm{Lr}-\mathrm{Lc}_{1}\right)+$ $(1-\mathrm{y})\left(-\mathrm{Lc}_{1}\right)=\mathrm{yLr}-\mathrm{Lc}_{1}$. The expected return on not providing loans of financial institutions is $\pi_{12}=\mathrm{y} \times 0+(1-\mathrm{y}) \times 0=0$. The average expected return of financial institutions is $\pi_{1}=\mathrm{x} \pi_{11}+$ $(1-\mathrm{x}) \pi_{12}$. Then the replicator dynamic model of financial institutions can be expressed as $\mathrm{F}(\mathrm{x})=$ $\mathrm{x}\left(\pi_{11}-\pi_{1}\right)=\mathrm{x}(1-\mathrm{x})\left(\operatorname{Lry}-\mathrm{Lc} c_{1}\right) . \operatorname{Make} \mathrm{F}(\mathrm{x})=0$, then $\mathrm{x}_{1}=0, \mathrm{x}_{2}=1, \mathrm{y}^{*}=\frac{\mathrm{c}_{1}}{\mathrm{r}}$. The expected return on applying for loans of the poor is $\pi_{21}=\mathrm{x}\left(\mathrm{kL} \beta-\mathrm{Lr}-\mathrm{Lc}_{2}\right)+(1-\mathrm{x})\left(-\mathrm{kL} \beta-\mathrm{Lc}_{2}\right)=$ $2 x k L \beta-x \operatorname{Lr}-\mathrm{kL} \beta-\mathrm{Lc}_{2}$. The expected return on not to applying for loans of the poor is $\pi_{22}=$ $\mathrm{x}(-\mathrm{kL} \beta)+(1-\mathrm{x})(-\mathrm{kL} \beta)=-\mathrm{kL} \beta$. The average expected return of the poor is $\pi_{2}=\mathrm{y} \pi_{21}+$ $(1-y) \pi_{22}$. Then the replicator dynamic model of the poor can be expressed as $\mathrm{F}(\mathrm{y})=\mathrm{y}\left(\pi_{21}-\pi_{2}\right)=$ $\mathrm{y}(1-\mathrm{y})\left[(2 \mathrm{~kL} \beta-\mathrm{Lr}) \mathrm{x}-\mathrm{Lc}_{2}\right]$. Make $\mathrm{F}(\mathrm{y})=0$, then $\mathrm{y}_{1}=0, \mathrm{y}_{2}=1, \mathrm{x}^{*}=\frac{\mathrm{c}_{2}}{2 \mathrm{k} \beta-\mathrm{r}}$. Five equilibrium points of the evolutionary game can be obtained that are $(0,0),(0,1),(1,0),(1,1),\left(x^{*}, \mathrm{y}^{*}\right)$.

However, the above five equilibrium points are local equilibrium points and not all of them are the equilibrium points of evolutionary stability strategy (ESS). Therefore, it is necessary to use a Jacobian matrix to verify the equilibrium points of ESS. Jacobian matrix can be obtained as shown in formula (1). If and only if the determinant value of the Jacobian matrix is greater than 0 and the trace value of the Jacobian matrix is less than 0, the equilibrium point of ESS can be obtained. Then the stability analysis results at each local equilibrium point are shown in Table 2.

$$
J=\left\{\begin{array}{ll}
\frac{\partial F(x)}{\partial x} & \frac{\partial F(x)}{\partial y} \\
\frac{\partial F(y)}{\partial x} & \frac{\partial F(y)}{\partial y}
\end{array}\right\}=\left\{\begin{array}{cc}
(1-2 x)\left(L r y-L_{1}\right) & x(1-x) \operatorname{Lr} \\
y(1-y)(2 k L \beta-L r) & (1-2 y)\left[(2 k L \beta-L r) x-L c_{2}\right]
\end{array}\right\}
$$

Table 2. The stability analysis results at each local equilibrium point.

\begin{tabular}{|c|c|c|c|c|c|}
\hline Point & $\operatorname{det}(J)$ & Sign & $\operatorname{tr}(J)$ & Sign & Stability \\
\hline$(0,0)$ & $\mathrm{Lc}_{1} \times \mathrm{Lc}_{2}$ & + & $-\mathrm{Lc}_{1}-\mathrm{Lc}_{2}$ & - & ESS \\
\hline$(0,1)$ & $\left(\mathrm{Lr}-\mathrm{Lc}_{1}\right) \times \mathrm{Lc}_{2}$ & + & $\left(\mathrm{Lr}-\mathrm{Lc}_{1}\right)+\mathrm{Lc}_{2}$ & + & No \\
\hline$(1,0)$ & $\begin{array}{c}\mathrm{Lc}_{1} \times \\
\left(2 \mathrm{~kL} \beta-\mathrm{Lr}-\mathrm{Lc}_{2}\right)\end{array}$ & + & $\begin{array}{c}\mathrm{Lc}_{1}+ \\
\left(2 \mathrm{~kL} \beta-\mathrm{Lr}-\mathrm{Lc}_{2}\right)\end{array}$ & + & No \\
\hline$(1,1)$ & $\begin{array}{c}\left(\mathrm{Lc}_{1}-\mathrm{Lr}\right) \times \\
{\left[-\left(2 \mathrm{~kL} \beta-\mathrm{Lr}-\mathrm{Lc}_{2}\right)\right]}\end{array}$ & + & $\begin{array}{c}\left(\mathrm{Lc}_{1}-\mathrm{Lr}\right)+ \\
{\left[-\left(2 \mathrm{~kL} \beta-\mathrm{Lr}-\mathrm{Lc}_{2}\right)\right]}\end{array}$ & - & ESS \\
\hline$\left(x^{*}, y^{*}\right)$ & 0 & & 0 & & No \\
\hline
\end{tabular}

So $(0,0)$ and $(1,1)$ are the two equilibrium point of ESS. As obtaining loans helps poverty reduction, the equilibrium $(1,1)$ will be the optimal equilibrium point, i.e., the poor apply for loans and financial institutions provide the loan as the purpose of inclusive finance. However, the equilibrium of evolutionary game is not achieved overnight. Financial institutions and poor people will adjust the strategy of action according to their own return, and make the choice of strategy in a dynamic adjustment process. As the region consisting of points $\left(\mathrm{x}^{*}, \mathrm{y}^{*}\right),(0,1),(1,1)$ and $(1,0)$ will converge to $(1,1)$, and the region consisting of points $\left(x^{*}, y^{*}\right),(0,1),(0,0)$ and $(1,0)$ will converge to $(0,0)$, so if $\left(x^{*}, y^{*}\right)$ is far from $(1,1)$, financial institutions and poor people will take the strategy $(1,1)$. For the point $\left(x^{*}, y^{*}\right)=\left(\frac{c_{2}}{2 k \beta-r}, \frac{c_{1}}{r}\right)$, when $k$ is larger, the region consisting of points $\left(x^{*}, y^{*}\right),(0,1),(1,1)$ and $(1,0)$ will converge to $(1,1)$.

In practice, the stronger the labor capacity of the poor, the higher the success rate of their production and management. Since the poor working-age population with the strongest labor capacity and development potential, therefore, compared with the poor non-working-age population, if financial institutions provide loans to poor working-age population, they will achieve the dual goals of maintaining institutional sustainable development and alleviating poverty. 


\section{Variables and Models}

\subsection{Variables Measurement}

\subsubsection{China'sRural Inclusive Financial Development Index (CRIFI)}

To reflect the development level of rural inclusive finance in China, it is necessary to construct an index system of rural inclusive financial development. At present, scholars have mainly measured the development level of inclusive finance from some perspectives of permeability, usability, utility, quality, and affordability—see Beck et al. [11], Sarma and Pais [24], Gupte et al. [25], Wang and Guan [26], Wu and Xiao [27], Chen et al. [28], Guo and Ding [29], Li et al. [30], Luo et al. [31], Zhang [32]-but their index system did not fully covered these five aspects above, and the inclusive development level studied by most of them is for the whole country rather than rural areas. Since the core of inclusive financial development is to enable more poor people and low-income people to enjoy equal access to financial services, and China's main battleground for poverty alleviation is in rural areas, especially in remote and the most difficult rural areas. Therefore, the development scope of inclusive finance in China is focused on the rural areas with the highest degree of financial exclusion and poverty in this article. Referring to the existing literature and combining it with the reality of rural financial development and the availability of rural financial data, we select the following indicators to construct the rural inclusive financial development index, as shown in Table 3. It should be noted that although internet finance and mobile finance are the new forms of inclusive finance and they have indeed greatly promoted the development of inclusive finance, considering they are mainly used in urban areas, the poor in rural areas are still largely excluded, so our index system does not include the related indicators.

Table 3. China's rural inclusive financial development index system.

\begin{tabular}{|c|c|c|}
\hline Aspect & Index & Property \\
\hline \multirow{4}{*}{ Permeability } & $\begin{array}{l}\text { Numbers of rural financial institutions per 10,000 } \\
\text { square kilometers in rural areas } 1\end{array}$ & positive \\
\hline & $\begin{array}{l}\text { Employees of rural financial institutions per 10,000 } \\
\text { square kilometers in rural areas }\end{array}$ & positive \\
\hline & $\begin{array}{l}\text { Numbers of rural financial institutions per } 10,000 \\
\text { people in rural areas }\end{array}$ & positive \\
\hline & $\begin{array}{l}\text { Employees of rural financial institutions per 10,000 } \\
\text { people in rural areas }\end{array}$ & positive \\
\hline \multirow{2}{*}{ Usability } & Per capita deposit of rural population & positive \\
\hline & Per capita loan of rural population & positive \\
\hline \multirow[t]{2}{*}{ Utility } & $\begin{array}{l}\text { Balance of deposits in rural financial institutions to } \\
\text { primary industry added value }{ }^{2}\end{array}$ & positive \\
\hline & $\begin{array}{c}\text { Balance of loan in rural financial institutions to } \\
\text { primary industry added value }{ }^{2}\end{array}$ & positive \\
\hline \multirow{2}{*}{ Quality } & Ratio of deposit to loan in rural financial institutions & negative \\
\hline & Bad loan ratio of rural financial institutions ${ }^{3}$ & negative \\
\hline Affordability & Percentage of floating range of RMB loan interest rate & negative \\
\hline \multicolumn{3}{|c|}{$\begin{array}{l}1 \text { The rural financial institutions in this article include rural commercial banks, rural cooperative banks, rural } \\
\text { credit cooperatives, village banks, rural loan companies, rural fund mutual aid cooperatives; Land area indicator is } \\
\text { substituted by agricultural land area. }{ }^{2} \text { Limited by provincial data, the deposit balance and loan balance in this } \\
\text { article are substituted by the deposit balance and loan balance of rural credit cooperatives. }{ }^{3} \text { In this article, the bad } \\
\text { loan ratio of rural financial institutions in each province is obtained by the conversion of the bad loan ratio of the } \\
\text { commercial banks in various provinces according to the ratio of bad loan between national rural commercial banks } \\
\text { and national commercial banks. }\end{array}$} \\
\hline
\end{tabular}


As Beijing, Tianjin, and Shanghai are the developed regions of China, where the incidence of poverty is almost zero, we discard their rural inclusive financial development. Furthermore, although the incidence of poverty in Chongqing and Tibet are very high, these areas have also been excluded, as their statistical data are insufficient. Finally, taking into account the availability of data and the pertinence of the research, we use "Euclidean distance method" as formula (2), similar to Sarma and Pais [24], Wang and Guan [26] and Chen et al. [28], to calculate the development level of rural inclusive finance in 26 provinces of China from 2007 to 2016. Data is derived from the China Statistical Yearbook, the China Financial Yearbook, the Regional Financial Operation Report and the wind database. Partial calculation results are shown in Table 4.

$$
\text { CRIFI }=1-\frac{\sqrt{\left(\mathrm{w}_{1 \mathrm{t}}-\mathrm{V}_{1 \mathrm{t}}\right)^{2}+\left(\mathrm{w}_{2 \mathrm{t}}-\mathrm{V}_{2 \mathrm{t}}\right)^{2}+\cdots+\left(\mathrm{w}_{\mathrm{mt}}-\mathrm{V}_{\mathrm{mt}}\right)^{2}}}{\sqrt{\mathrm{w}_{1 \mathrm{t}}{ }^{2}+\mathrm{w}_{2 \mathrm{t}}{ }^{2}+\cdots \mathrm{w}_{\mathrm{mt}}{ }^{2}}}
$$

Table 4. General situation of China's rural inclusive financial development from 2007 to 2016.

\begin{tabular}{ccccccccc}
\hline Region & Province & CRIFI & Rank & Permeability & Usability & Utility & Quality & Affordability \\
\hline \multirow{6}{*}{ Eastern } & Guangdong & 0.539 & 2 & 0.666 & 0.712 & 0.365 & 0.683 & 0.459 \\
region & Hebei & 0.469 & 3 & 0.525 & 0.694 & 0.363 & 0.732 & 0.131 \\
& Zhejiang & 0.467 & 4 & 0.819 & 0.450 & 0.236 & 0.508 & 0.049 \\
& Shandong & 0.445 & 5 & 0.696 & 0.492 & 0.214 & 0.570 & 0.203 \\
& Liaoning & 0.364 & 7 & 0.495 & 0.558 & 0.163 & 0.501 & 0.372 \\
& Jiangsu & 0.321 & 9 & 0.761 & 0.102 & 0.044 & 0.647 & 0.268 \\
& Fujian & 0.258 & 14 & 0.308 & 0.391 & 0.133 & 0.639 & 0.216 \\
& Hainan & 0.237 & 16 & 0.291 & 0.446 & 0.086 & 0.749 & 0.663 \\
Central & Average & 0.388 & & 0.570 & 0.480 & 0.200 & 0.629 & 0.295 \\
\hline \multirow{5}{*}{ region } & Shanxi & 0.622 & 1 & 0.508 & 0.837 & 1.000 & 0.450 & 0.303 \\
& Henan & 0.397 & 6 & 0.597 & 0.331 & 0.218 & 0.642 & 0.249 \\
& Jiangxi & 0.273 & 11 & 0.309 & 0.280 & 0.205 & 0.568 & 0.217 \\
& Hunan & 0.241 & 15 & 0.341 & 0.199 & 0.111 & 0.642 & 0.360 \\
& Anhui & 0.234 & 18 & 0.443 & 0.033 & 0.055 & 0.675 & 0.373 \\
& Jilin & 0.230 & 19 & 0.268 & 0.332 & 0.120 & 0.531 & 0.541 \\
& Heilongjiang & 0.184 & 22 & 0.170 & 0.382 & 0.121 & 0.483 & 0.371 \\
& Hubei & 0.179 & 24 & 0.278 & 0.091 & 0.042 & 0.701 & 0.652 \\
Average & 0.295 & & 0.364 & 0.311 & 0.234 & 0.586 & 0.383 \\
\hline \multirow{6}{*}{ region } & Ningxia & 0.324 & 8 & 0.226 & 0.534 & 0.388 & 0.610 & 0.260 \\
& Shaanxi & 0.320 & 10 & 0.249 & 0.528 & 0.342 & 0.640 & 0.497 \\
& Guizhou & 0.263 & 12 & 0.191 & 0.290 & 0.339 & 0.658 & 0.274 \\
& Sichuan & 0.259 & 13 & 0.253 & 0.341 & 0.223 & 0.468 & 0.275 \\
& Yunnan & 0.236 & 17 & 0.081 & 0.503 & 0.390 & 0.687 & 0.408 \\
& Gansu & 0.228 & 20 & 0.139 & 0.303 & 0.309 & 0.593 & 0.491 \\
& Guangxi & 0.222 & 21 & 0.200 & 0.325 & 0.176 & 0.710 & 0.474 \\
& Inn Mongolia & 0.181 & 23 & 0.105 & 0.563 & 0.161 & 0.574 & 0.190 \\
& Xinjiang & 0.151 & 25 & 0.044 & 0.448 & 0.176 & 0.573 & 0.747 \\
& Qinghai & 0.149 & 26 & 0.033 & 0.296 & 0.248 & 0.380 & 0.781 \\
& Average & 0.233 & & 0.152 & 0.413 & 0.275 & 0.589 & 0.440 \\
\hline
\end{tabular}

Data sources: Authors' calculations.

In formula (2), $\mathrm{w}_{\mathrm{mt}}$ is the weight of index $\mathrm{m}$ in Table 1 in year $\mathrm{t}$, which is determined by the coefficient of variation method as per Zhou et al. [6]. That is the ratio of the standard deviation to the average of the index in all provinces in each year. $V_{m t}$ is the calculated value of index $m$ in Table 1 in year $t$. That is, the data obtained by unifying the actual data and multiply it by the weight of index.

As shown in Table 4, there is a wide gap between regions in the development level of rural inclusive finance. The permeability, usability, and quality of rural inclusive financial development in eastern China are relatively high, but utility and affordability of inclusive financial development are relatively low. Therefore, in the eastern region it is necessary to further improve the use efficiency of the poverty alleviation funds and reduce the transaction costs of financial services. The development of 
inclusive finance in the central and western regions is relatively backward, so they should strengthen the development of all aspects of rural inclusive finance, in particular to further increase the coverage of financial institutions and support those in more rural poverty to have access to financial resources.

\subsubsection{Multidimensional Poverty Index}

At present, the research on multidimensional poverty mainly identifies the multidimensional poverty of households or farmers from the aspects of income, education, medical treatment, insurance, assets, and living standards, as per Wang and Alkire [33], Li [34], Zou and Fang [35], Alkire and Santos [36], Santos [37], Alkire and Seth [38], Zhang and Zhou [39], Guo and Zhou [40]. However, there is little research on individual multidimensional poverty, in which the index selection only includes income, health, education, and insurance dimensions, and does not emphasize the development of production or employment [41-43]. Since inclusive financial services are intended primarily for individuals rather than households, it is more effective and accurate to identify the poor from the individual level than from the family level. Furthermore, the existing literature only focuses on income, health, education, and insurance poverties, but neglects employment poverty. In fact, unemployment is also a crucial cause of individual poverty, which directly determines people's income level and social status [44]. Therefore, combined with factors affecting individual poverty, we calculate the multidimensional poverty of rural working-age population from five dimensions of income (economic capability), health (physical function), education (learning ability), insurance (risk-resisting ability) and employment (survival ability) by using the "dual cutoff method" of Alkire and Foster [45,46]. All dimensional indicators and deprivation cutoffs refer to the existing literature, the UN Millennium Development goals, Chinese poverty line, and the characteristics of survey data. There is equal weight for each indicator. Details are shown in Table 5.

Table 5. Five poverty dimensions and deprivation cutoffs.

\begin{tabular}{|c|c|}
\hline Dimensions & Deprivation Cutoffs \\
\hline Income & $\begin{array}{c}\text { Income below the income poverty line } 2300 \mathrm{RMB} \text { yuan (comparable prices based } \\
\text { on year 2010) is regarded as "Income poverty". }\end{array}$ \\
\hline Health & $\begin{array}{l}\text { If body mass index (BMI) is outside the range of }\left(18.5 \mathrm{~kg} / \mathrm{m}^{2}, 30 \mathrm{~kg} / \mathrm{m}^{2}\right) \text { and } \\
\text { self-rated health is unhealthy, that is regarded as "Health poverty". }\end{array}$ \\
\hline Education & $\begin{array}{l}\text { Failure to complete compulsory primary education (maximum length of education } \\
\text { less than } 6 \text { years) is regarded as "Education poverty". }\end{array}$ \\
\hline Insurance & $\begin{array}{l}\text { Failure to enjoy any kind of endowment insurance or medical insurance is } \\
\text { regarded as "Insurance poverty". }\end{array}$ \\
\hline Employment & $\begin{array}{c}\text { No job now and no formal work experience for more than six months is regarded } \\
\text { as "Employ poverty" }{ }^{1} \text {. }\end{array}$ \\
\hline
\end{tabular}

${ }^{1}$ Employment here includes do agricultural work and self-employment.

"Dual cutoff method" is also called "AF method", which uses deprivation cutoffs and poverty cutoffs to measure people's multidimensional poverty and was created by Alkire and Foster [45,46]. Assuming that the achievement level of ith individual in jth dimension is $\mathrm{y}_{\mathrm{ij}}(\mathrm{i}=1,2, \cdots \mathrm{n} ; \mathrm{j}=1,2, \cdots \mathrm{d})$, so an $(\mathrm{n} \times \mathrm{d})$ data matrix $\mathrm{Y}$ is formed for $\mathrm{n}$ individuals and $\mathrm{d}$ dimensions. The row vector $y_{i j}=\left(y_{i 1}, y_{i 2}, \cdots y_{i d}\right)$ is the achievement level of each individual in a given dimension, and the column vector $y_{i j}=\left(y_{1 j}, y_{2 j}, \cdots y_{n j}\right)$ is the achievement level of each dimension for a given individual. A vector $\mathrm{z}=\left(\mathrm{z}_{1}, \cdots, \mathrm{z}_{\mathrm{d}}\right)$ of deprivation cutoffs is used to determine whether an individual is deprived. If $y_{\mathrm{ij}}$ falls short of the respective deprivation cutoff $\mathrm{z}_{\mathrm{j}}$, then this individual is said to be deprived in that dimension and considered to be poverty in that dimension; If $y_{i j}$ is at least as great as the respective deprivation cutoff $z_{j}$, then this individual is not deprived in that dimension and not considered to be poverty in that dimension. The deprivation vector $\mathrm{g}_{\mathrm{ij}}^{0}$ is used to represent an individual's deprivation. If ith individual is deprived in $\mathrm{jth}$ dimension, 
$\mathrm{g}_{\mathrm{ij}}=1$; if ith individual is not deprived in jth dimension, $\mathrm{g}_{\mathrm{ij}}=0$. The deprivation vector of all individuals consists of a deprivation matrix $\mathrm{g}^{0}=\left[\mathrm{g}_{\mathrm{ij}}^{0}\right]$, which is composed of 0 and 1 elements. A column vector $c_{i j}=\left(c_{i 1}, c_{i 2}, \cdots c_{i d}\right)^{\prime}$ of deprivation counts reflects the breadth of each individual's deprivation, so $\mathrm{c}_{\mathrm{ij}}=\sum \mathrm{g}_{\mathrm{ij}}$. A poverty cutoff $\mathrm{k}(0<k \leq d)$ is used to determine whether an individual is a multidimensional poverty people. If the deprivation counts $c_{i j}$ falls short of the poverty cutoff $k$, the individual is not considered to be a multidimensional poverty people. In contrast, if the deprivation counts $c_{i j}$ is at least as great as the poverty cutoff $k$, the individual is considered to be in multidimensional poverty. According to deprivation counts $\mathrm{c}_{\mathrm{ij}}, \mathrm{n}$ individuals and $\mathrm{d}$ dimensions, the value of multidimensional poverty $\mathrm{M}$ can be calculated, the formula is $\mathrm{M}=\sum_{1}^{\mathrm{n}} \mathrm{c}_{\mathrm{i}}(\mathrm{k}) / \mathrm{nd}$. The headcount ratio $\mathrm{H}$ is the proportion of multidimensional poverty people, if there are $\mathrm{q}$ multidimensional poverty peoples among $\mathrm{n}$ individuals, the headcount ratio $\mathrm{H}$ is calculated by $\mathrm{q} / \mathrm{n}$. The intensity $\mathrm{A}$ is the average deprivation share among the multidimensional poverty people, and it can be calculated by $\sum_{1}^{n} c_{i}(k) / q d$. The relationship between $M, H$ and $A$ is $M=H \times A$.

In this article, data of identifying multidimensional poverty population comes from the database of CFPS, which has been surveyed since 2010 for full sample data and each investigation lasts two years. To ensure the continuity and comparability of the samples, we select the survey data from 2010, 2012, 2014 and 2016, and only selects 21 provinces from 30 provinces that have been involved in the survey and rural inclusive financial development index have been calculated. Among the 30 provinces surveyed by CFPS, Inner Mongolia and Hainan Province were only included in the survey in 2014, and the valid samples were only 10 and 5, respectively. Qinghai were only included in the survey in 2012, and the valid samples were only 1 . Ningxia and Xinjiang were included in the survey in 2012 and 2014, but their valid samples were only 6 and 19, respectively; Beijing, Tianjin, Shanghai, and Chongqing are dismissible for not calculating the rural inclusive financial development index. Thus, the nine provinces mentioned above are all excluded. In summary, the 21 provinces and regions are Hebei Province, Shanxi Province, Liaoning Province, Jilin Province, Heilongjiang Province, Jiangsu Province, Zhejiang Province, Anhui Province, Fujian Province, Jiangxi Province, Shandong Province, Henan Province, Hubei Province, Hunan Province, Guangdong Province, Guangxi Zhuang Autonomous region, Sichuan Province, Guizhou Province, Yunnan Province, Shaanxi Province, and Gansu Province. To ensure the validity of the sample, missing values and the abnormal values are deleted directly, and 20,094 valid samples are retained to calculate the multidimensional poverty of the rural population. Among them, there are 10,987 valid samples in 2010, 4582 valid samples in 2012, 3865 valid samples in 2014, and 660 valid samples in 2016. Partial calculation results are shown in Table 6. As shown in Table 6, the multidimensional poverty situation of rural population has improved as a whole, but the task of targeted poverty reduction and alleviation has not yet been completed; some rural populations still have problems of low income, ill health, inadequate education, lack of insurance, and unemployment. Health poverty and education poverty are the main poverty problems faced by them. It is necessary to continue to intensify efforts of poverty alleviation. 
Table 6. Multidimensional poverty of rural population from 2010 to 2016.

\begin{tabular}{|c|c|c|c|c|c|c|c|c|c|}
\hline \multirow{2}{*}{\multicolumn{2}{|c|}{ Dimensions Year }} & \multicolumn{3}{|c|}{ Poverty Status } & \multicolumn{5}{|c|}{ Dimension Contribution Rate } \\
\hline & & $\mathbf{M}$ & $\mathbf{H}$ & A & Income & Health & Education & Insurance & Employ \\
\hline \multirow{5}{*}{$\begin{array}{c}\text { One } \\
\text { dimension }\end{array}$} & 2010 & 0.212 & 0.626 & 0.336 & 0.251 & 0.208 & 0.311 & 0.109 & 0.121 \\
\hline & 2012 & 0.126 & 0.452 & 0.274 & 0.178 & 0.370 & 0.354 & 0.021 & 0.077 \\
\hline & 2014 & 0.175 & 0.516 & 0.334 & 0.241 & 0.275 & 0.244 & 0.069 & 0.171 \\
\hline & 2016 & 0.174 & 0.593 & 0.292 & 0.085 & 0.243 & 0.298 & 0.209 & 0.165 \\
\hline & Avg & 0.172 & 0.547 & 0.309 & 0.189 & 0.274 & 0.302 & 0.102 & 0.133 \\
\hline \multirow{5}{*}{$\begin{array}{c}\text { Two } \\
\text { dimensions }\end{array}$} & 2010 & 0.147 & 0.302 & 0.483 & 0.264 & 0.210 & 0.299 & 0.099 & 0.127 \\
\hline & 2012 & 0.064 & 0.142 & 0.447 & 0.207 & 0.341 & 0.336 & 0.019 & 0.096 \\
\hline & 2014 & 0.118 & 0.234 & 0.498 & 0.274 & 0.247 & 0.239 & 0.051 & 0.189 \\
\hline & 2016 & 0.099 & 0.218 & 0.463 & 0.104 & 0.217 & 0.290 & 0.189 & 0.201 \\
\hline & Avg & 0.107 & 0.224 & 0.473 & 0.212 & 0.254 & 0.291 & 0.090 & 0.153 \\
\hline \multirow{5}{*}{$\begin{array}{l}\text { Three } \\
\text { dimensions }\end{array}$} & 2010 & 0.069 & 0.106 & 0.644 & 0.265 & 0.225 & 0.275 & 0.092 & 0.143 \\
\hline & 2012 & 0.020 & 0.034 & 0.603 & 0.258 & 0.329 & 0.305 & 0.027 & 0.081 \\
\hline & 2014 & 0.061 & 0.090 & 0.667 & 0.273 & 0.253 & 0.232 & 0.027 & 0.215 \\
\hline & 2016 & 0.032 & 0.049 & 0.640 & 0.123 & 0.241 & 0.235 & 0.212 & 0.189 \\
\hline & Avg & 0.045 & 0.070 & 0.639 & 0.230 & 0.262 & 0.262 & 0.089 & 0.157 \\
\hline \multirow{5}{*}{$\begin{array}{c}\text { Four } \\
\text { dimensions }\end{array}$} & 2010 & 0.019 & 0.023 & 0.808 & 0.232 & 0.220 & 0.236 & 0.128 & 0.185 \\
\hline & 2012 & 0.000 & 0.000 & 0.800 & 0.000 & 0.250 & 0.250 & 0.250 & 0.250 \\
\hline & 2014 & 0.026 & 0.033 & 0.800 & 0.250 & 0.250 & 0.250 & 0.000 & 0.250 \\
\hline & 2016 & 0.008 & 0.010 & 0.800 & 0.125 & 0.194 & 0.250 & 0.194 & 0.236 \\
\hline & Avg & 0.013 & 0.017 & 0.802 & 0.152 & 0.229 & 0.246 & 0.143 & 0.230 \\
\hline \multirow{5}{*}{$\begin{array}{c}\text { Five } \\
\text { dimensions }\end{array}$} & 2010 & 0.001 & 0.001 & 0.000 & 0.200 & 0.200 & 0.200 & 0.200 & 0.200 \\
\hline & 2012 & 0.000 & 0.000 & 0.000 & 0.000 & 0.000 & 0.000 & 0.000 & 0.000 \\
\hline & 2014 & 0.000 & 0.000 & 0.000 & 0.000 & 0.000 & 0.000 & 0.000 & 0.000 \\
\hline & 2016 & 0.000 & 0.000 & 0.000 & 0.000 & 0.000 & 0.000 & 0.000 & 0.000 \\
\hline & Avg & 0.000 & 0.000 & 0.000 & 0.050 & 0.050 & 0.050 & 0.050 & 0.050 \\
\hline
\end{tabular}

Data sources: Authors' calculations.

\subsection{Model Selection and Variable Description}

To test whether rural inclusive financial development can effectively reduce the multidimensional poverty of the rural population, this article constructs a benchmark regression model (3). In model (3), samples are divided into two groups: the working-age population and the non-working-age population.

$$
\mathrm{MP}_{\mathrm{it}}=\alpha_{1}+\beta_{1} \mathrm{CRIFI}_{\mathrm{it}}+\theta_{1} \mathrm{X}_{\mathrm{it}}+\varepsilon_{\mathrm{it}}
$$

$\mathrm{MP}_{\text {it }}$ is the multidimensional poverty situation of the rural population, which describes whether the people are in multidimensional poverty on one of the five dimensions of income, health, education, insurance, and employment. If the rural population is in multidimensional poverty, $\mathrm{MP}_{\mathrm{it}}$ takes 1 , and if not, $\mathrm{MP}_{\text {it }}$ takes 0 . In addition, $\mathrm{CRIFI}_{\mathrm{it}}$ means Chinese rural inclusive financial development index, $X_{i t}$ is control variables, including personal characteristics variables such as gender, age, the square of age, household register, marital status, and family characteristics variables such as family size, family burden ratio, etc. $\varepsilon_{i t}$ is the random error. Since the explained variables in the benchmark regression model (3) are virtual variables, the panel Logit model is used for estimating. The main variable description is shown in Table 7. 
Table 7. Variable description.

\begin{tabular}{|c|c|c|c|c|c|c|}
\hline Variable & Description & $\mathbf{N}$ & Mean & St dev & Min & Max \\
\hline $\mathrm{MP}_{\text {it }}$ & $\begin{array}{c}\text { Poverty }=1 \\
\text { non-poverty }=0\end{array}$ & 20,094 & 0.559 & 0.497 & 0 & 1 \\
\hline CRIFI & continuous variable & 20,094 & 0.356 & 0.130 & 0.136 & 0.653 \\
\hline crifi1 & permeability & 20,094 & 0.414 & 0.220 & 0.069 & 0.896 \\
\hline crifi2 & usability & 20,094 & 0.480 & 0.251 & 0 & 1 \\
\hline crifi3 & utility & 20,094 & 0.280 & 0.208 & 0 & 1 \\
\hline crifi4 & quality & 20,094 & 0.625 & 0.151 & 0.023 & 0.893 \\
\hline crifi5 & affordability & 20,094 & 0.311 & 0.191 & 0 & 1 \\
\hline gender & men $=1 ;$ women $=0$ & 20,094 & 0.606 & 0.489 & 0 & 1 \\
\hline age & & 20,094 & 43.027 & 15.257 & 16 & 99 \\
\hline age2 & continuous variable & 20,094 & 2084.056 & 1403.238 & 256 & 9801 \\
\hline marriage & $\begin{array}{c}\text { married }=0 \text {; others }=1 \\
\text { (Others include unmarried, } \\
\text { cohabitation, divorce, } \\
\text { widowhood.) }\end{array}$ & 20,094 & 0.189 & 0.391 & 0 & 1 \\
\hline registration & $\begin{array}{c}\text { rural household }=1 ; \\
\text { non-rural household }=0\end{array}$ & 20,094 & 0.915 & 0.279 & 0 & 1 \\
\hline family size & & 20,094 & 4.560 & 1.893 & 1 & 26 \\
\hline burden ratio & & 20,094 & 1.778 & 2.748 & 0.003 & 100 \\
\hline district & Eastern $=1$; Central $=2$; West $=$ & 20,094 & 1.992 & 0.839 & 1 & 3 \\
\hline
\end{tabular}

\section{Empirical Results}

\subsection{Benchmark Regression Results}

According to the benchmark regression model (3), the influence coefficient and marginal effect of rural inclusive finance development on multidimensional poverty alleviation of rural population is shown in Table 8; columns (1), (3) are the influence coefficient, and columns (2), (4) are the marginal effect. From the empirical results, the p-value corresponding to all Wald statistics was 0.000 , so model (3) passed the test as a whole. Then, it can be seen that the influence coefficient and marginal effect of rural inclusive finance on the multidimensional poverty of rural working-age population are significantly negative, but the influence coefficient and marginal effect of rural inclusive finance on the multidimensional poverty of rural non-working-age population are not significant. It suggests that in the case of other factors remaining unchanged, the development of rural inclusive finance will reduce the probability of rural working-age population falling into multidimensional poverty by $43.8 \%$, but there is no significant impact of rural inclusive financial development on the poverty situation of rural non-working-age population. Therefore, compared with the poor non-working-age population, if financial institutions provide loans to poor working-age population, they will achieve the dual goals of maintaining institutional sustainable development and alleviating poverty. However, non-working-age population is less able to work, so the effect of inclusive finance on their poverty alleviation is not significant, which also proves the reason for there still existing financial exclusion to a small number of poor people.

In addition, from the empirical results we can also find that the influence coefficient and marginal effect of gender and the multidimensional poverty of rural population is significantly negative, which is shown by men being less likely to fall into multidimensional poverty than women in the case of other factors remaining unchanged. The relationship between age and the multidimensional poverty of the rural population is an "inverted U-shaped". The coefficient and marginal effect of marital status and the multidimensional poverty of rural population are significantly positive, indicating that the population in the marital status of unmarried, cohabiting, divorced, and widowed has a higher probability of falling into multidimensional poverty than those in the married state. The coefficient and marginal effect of household register and the multidimensional poverty of rural population is 
significantly positive, indicating that the population with a rural household register is more likely to fall into multidimensional poverty than those with a non-rural household register. Furthermore, the coefficient and marginal effect of family size and the multidimensional poverty of rural population is also negative. There is also a negative correlation between family burden ratio and multidimensional poverty of rural population. It shows that the rural population with lower family burden is more likely to get rid of poverty through hard work, and the rural population with higher family burden is more likely to fall into multidimensional poverty.

Table 8. Impact of rural inclusive financial development on multidimensional poverty.

\begin{tabular}{|c|c|c|c|c|c|c|c|c|}
\hline \multirow{3}{*}{ Variables } & \multicolumn{4}{|c|}{ Benchmark Regression } & \multicolumn{4}{|c|}{ Robustness Test } \\
\hline & (1) & (2) & (3) & (4) & (5) & (6) & (7) & (8) \\
\hline & \multicolumn{2}{|c|}{ Working-Age } & \multicolumn{2}{|c|}{ Non-Working Age } & \multicolumn{2}{|c|}{ Working-Age } & \multicolumn{2}{|c|}{ Non-Working Age } \\
\hline CRIFI & $\begin{array}{c}-2.035^{* * *} \\
(0.632)\end{array}$ & $\begin{array}{c}-0.438 * * * \\
(0.136)\end{array}$ & $\begin{array}{l}-2.966 \\
(2.405)\end{array}$ & $\begin{array}{l}-0.318 \\
(0.258)\end{array}$ & $\begin{array}{c}-1.604^{* * *} \\
(0.528)\end{array}$ & $\begin{array}{c}-0.345^{* * *} \\
(0.113)\end{array}$ & $\begin{array}{l}-3.525 \\
(2.251)\end{array}$ & $\begin{array}{l}-0.378 \\
(0.241)\end{array}$ \\
\hline gender & $\begin{array}{c}-1.024^{* * *} \\
(0.036)\end{array}$ & $\begin{array}{c}-0.220^{* * *} \\
(0.007)\end{array}$ & $\begin{array}{c}-1.892^{* * *} \\
(0.198)\end{array}$ & $\begin{array}{c}-0.203^{* * *} \\
(0.020)\end{array}$ & $\begin{array}{c}-1.024^{* * *} \\
(0.036)\end{array}$ & $\begin{array}{c}-0.220 * * * \\
(0.007)\end{array}$ & $\begin{array}{c}-1.894^{* * *} \\
(0.198)\end{array}$ & $\begin{array}{c}-0.203^{* * *} \\
(0.020)\end{array}$ \\
\hline age & $\begin{array}{c}-0.104^{* * *} \\
(0.012)\end{array}$ & $\begin{array}{c}-0.022^{* * *} \\
(0.003)\end{array}$ & $\begin{array}{c}-0.948^{* *} \\
(0.400)\end{array}$ & $\begin{array}{c}-0.102^{* *} \\
(0.043)\end{array}$ & $\begin{array}{c}-0.104^{* * *} \\
(0.012)\end{array}$ & $\begin{array}{c}-0.022 * * * \\
(0.003)\end{array}$ & $\begin{array}{c}-0.956^{* *} \\
(0.401)\end{array}$ & $\begin{array}{c}-0.102 \text { ** } \\
(0.043)\end{array}$ \\
\hline age2 & $\begin{array}{c}0.002 * * * \\
(0.000)\end{array}$ & $\begin{array}{c}0.000^{* * *} \\
(0.000)\end{array}$ & $\begin{array}{c}0.008^{* * *} \\
(0.003)\end{array}$ & $\begin{array}{c}0.001^{* * *} \\
(0.000)\end{array}$ & $\begin{array}{c}0.002^{* * *} \\
(0.000)\end{array}$ & $\begin{array}{c}0.000^{* * *} \\
(0.000)\end{array}$ & $\begin{array}{c}0.008^{* * *} \\
(0.003)\end{array}$ & $\begin{array}{c}0.001 * * * \\
(0.000)\end{array}$ \\
\hline marriage & $\begin{array}{c}0.219^{* * *} \\
(0.058)\end{array}$ & $\begin{array}{c}0.047^{* * *} \\
(0.012)\end{array}$ & $\begin{array}{c}0.637^{* * *} \\
(0.220)\end{array}$ & $\begin{array}{c}0.068^{* * *} \\
(0.023)\end{array}$ & $\begin{array}{c}0.219^{* * *} \\
(0.058)\end{array}$ & $\begin{array}{c}0.047^{* * *} \\
(0.012)\end{array}$ & $\begin{array}{c}0.638^{* * *} \\
(0.220)\end{array}$ & $\begin{array}{c}0.068^{* * *} \\
(0.023)\end{array}$ \\
\hline registration & $\begin{array}{c}0.485^{* * *} \\
(0.071)\end{array}$ & $\begin{array}{c}0.104^{* * *} \\
(0.015)\end{array}$ & $\begin{array}{c}0.488^{* * *} \\
(0.168)\end{array}$ & $\begin{array}{c}0.052 * * * \\
(0.018)\end{array}$ & $\begin{array}{c}0.483^{* * *} \\
(0.071)\end{array}$ & $\begin{array}{c}0.104^{* * *} \\
(0.015)\end{array}$ & $\begin{array}{c}0.490^{* * *} \\
(0.168)\end{array}$ & $\begin{array}{c}0.052^{* * *} \\
(0.018)\end{array}$ \\
\hline family size & $\begin{array}{l}-0.017 \\
(0.011)\end{array}$ & $\begin{array}{l}-0.004 \\
(0.002)\end{array}$ & $\begin{array}{l}-0.035 \\
(0.030)\end{array}$ & $\begin{array}{l}-0.004 \\
(0.003)\end{array}$ & $\begin{array}{l}-0.017 \\
(0.010)\end{array}$ & $\begin{array}{l}-0.004 \\
(0.002)\end{array}$ & $\begin{array}{l}-0.035 \\
(0.030)\end{array}$ & $\begin{array}{l}-0.004 \\
(0.003)\end{array}$ \\
\hline $\begin{array}{l}\text { burden } \\
\text { ratio }\end{array}$ & $\begin{array}{c}-0.032^{* * *} \\
(0.011)\end{array}$ & $\begin{array}{c}-0.007^{* * *} \\
(0.002)\end{array}$ & $\begin{array}{l}-0.015 \\
(0.022)\end{array}$ & $\begin{array}{l}-0.002 \\
(0.002)\end{array}$ & $\begin{array}{c}-0.032 \text { *** } \\
(0.011)\end{array}$ & $\begin{array}{c}-0.007^{* * *} \\
(0.002)\end{array}$ & $\begin{array}{l}-0.015 \\
(0.022)\end{array}$ & $\begin{array}{l}-0.002 \\
(0.002)\end{array}$ \\
\hline year & $\mathrm{Y}$ & $\mathrm{Y}$ & $\mathrm{Y}$ & $\mathrm{Y}$ & $\mathrm{Y}$ & $\mathrm{Y}$ & $\mathrm{Y}$ & $\mathrm{Y}$ \\
\hline province & $\mathrm{Y}$ & $\mathrm{Y}$ & $\mathrm{Y}$ & $\mathrm{Y}$ & $\mathrm{Y}$ & $\mathrm{Y}$ & $\mathrm{Y}$ & $\mathrm{Y}$ \\
\hline Intercept & $\begin{array}{c}2.412 * * * \\
(0.391)\end{array}$ & - & $\begin{array}{c}33.153 * * \\
(13.671)\end{array}$ & $\begin{array}{l}- \\
-\end{array}$ & $\begin{array}{c}2.268 * * * \\
(0.369)\end{array}$ & $\begin{array}{l}- \\
-\end{array}$ & $\begin{array}{c}33.842^{* *} \\
(13.696)\end{array}$ & $\begin{array}{l}- \\
-\end{array}$ \\
\hline $\mathrm{N}$ & 15,590 & 15,590 & 2603 & 2603 & 15,590 & 15,590 & 2603 & 2603 \\
\hline Quasi R2 & 0.106 & 0.106 & 0.177 & 0.177 & 0.106 & 0.106 & 0.178 & 0.178 \\
\hline Wald test & 1928.38 & - & 255.34 & - & 1927.28 & - & 256.41 & - \\
\hline $\mathrm{p}$-value & 0.000 & - & 0.000 & - & 0.000 & - & 0.000 & - \\
\hline
\end{tabular}

Note: The values in parentheses are standard deviations; ${ }^{*}, * *, * * *$ indicate the level of significance of $10 \%, 5 \%$, and $1 \%$, respectively. Data is calculated by authors using Stata 13 .

\subsection{Robustness Test}

Based on Sarma and Pais [24], Sarma [47] improved the calculation method of the inclusive financial development index. In contrast to the calculation method of the normalized inverse Euclidian distance between the achievement point and the ideal point in the past, Sarma [47] uses a simple average of the normalized Euclidian distance between the achievement point and the worst point and the normalized inverse Euclidian distance between the achievement point and the ideal point as formula (4). Therefore, we use this new method to recalculate the CRIFI, and apply the modified index to the benchmark model (3). The results are unchanged as shown in Table 8.

$$
\text { CRIFI }=\frac{1}{2}\left[\frac{\sqrt{\left(\mathrm{V}_{1 \mathrm{t}}\right)^{2}+\left(\mathrm{V}_{2 \mathrm{t}}\right)^{2}+\cdots+\left(\mathrm{V}_{\mathrm{mt}}\right)^{2}}}{\sqrt{\mathrm{w}_{1 \mathrm{t}}{ }^{2}+\mathrm{w}_{2 \mathrm{t}}{ }^{2}+\cdots \mathrm{w}_{\mathrm{mt}}{ }^{2}}}+\left(1-\frac{\sqrt{\left(\mathrm{w}_{1 \mathrm{t}}-\mathrm{V}_{1 \mathrm{t}}\right)^{2}+\left(\mathrm{w}_{2 \mathrm{t}}-\mathrm{V}_{2 \mathrm{t}}\right)^{2}+\cdots+\left(\mathrm{w}_{\mathrm{mt}}-\mathrm{V}_{\mathrm{mt}}\right)^{2}}}{\sqrt{\mathrm{w}_{1 \mathrm{t}}{ }^{2}+\mathrm{w}_{2 \mathrm{t}} \mathrm{t}^{2}+\cdots \mathrm{w}_{\mathrm{mt}}{ }^{2}}}\right)\right]
$$

From the results of the robustness test we can also find that the influence coefficient and marginal effect of rural inclusive finance on the multidimensional poverty of rural working-age population are significantly negative, but the influence coefficient and marginal effect of rural inclusive finance on the multidimensional poverty of rural non-working-age population are not significant. It suggests our conclusion is robust. 


\subsection{Endogenous Test}

As finance is an important method of development-oriented poverty alleviation, the Chinese government has issued several documents to support the financial sector in strengthening poverty alleviation, especially in areas with deep poverty, so multidimensional poverty of rural population may also affect the development of inclusive finance. Furthermore, there may be some endogenous problems in model setting, such as missing variables, which make the estimation result biased. Therefore, we select an index that lags two years behind the rural inclusive financial development as the instrumental variable, and use the Ivprobit model for a two-step method. The regression result is shown in Table 9. The result of Wald endogenous test shows that the model is endogenetic and the instrumental variable is highly correlated with the endogenous variable. However, the endogenous influence can be eliminated by Ivprobit model regression, and the regression result is consistent with the benchmark model.

Table 9. Endogenous test.

\begin{tabular}{ccccc}
\hline & \multicolumn{2}{c}{ Working-Age } & \multicolumn{2}{c}{ Non-Working Age } \\
\hline Variables & First Step & Second Step & First Step & Second Step \\
\hline IFI & \multicolumn{3}{c}{} & -0.697 \\
& & $-2.423^{* * *}$ & $(1.943)$ \\
IFI2(instrumental variable) & $0.610^{* * *}$ & $(0.618)$ & $0.647^{* * *}$ & \\
& $(0.005)$ & & $(0.011)$ & Y \\
$X_{\text {it }}$ & Y & Y & Y & Y \\
year & Y & Y & Y & Y \\
province & Y & Y & 2603 & 2603 \\
\hline N & 15,590 & 15,590 & 0.45 & 0.45 \\
\hline Wald test & 6.24 & 6.24 & 0.5003 & 0.5003 \\
\hline P & 0.013 & 0.013 &
\end{tabular}

Note: The values in parentheses are standard deviations; *** indicate the level of significance of $1 \%$, respectively. Data is calculated by authors using Stata13.

\subsection{Further analysis}

The result of benchmark regression has proved that inclusive financial development can effectively alleviate the multidimensional poverty of the working-age population. In addition, to study which aspects of inclusive finance are more effective for poverty reduction of the working-age population, we study the poverty reduction effectiveness of permeability, usability, utility, quality, and affordability of inclusive finance based on model (3). The test result is shown in Table 10. We can see that the development of inclusive finance in aspects of permeability, usability, and utility can significantly reduce multidimensional poverty, but the development of inclusive finance in aspects of quality and affordability has no significant effect on the alleviation of multidimensional poverty. As the development of "permeability" is manifested in the expansion of the network coverage of financial institutions and the further sinking of financial services, which can extend the financial markets to more remote and poorer areas. The development of "usability" is manifested in the increased demand and participation of rural inclusive finance among rural poor people, so that more of them can have access to financial services without the restriction of mortgage conditions. The development of "utility" is manifested in the expansion of agricultural credit scale and the enhancement of the capacity to promote agricultural production and rural economic development, which is conducive to letting the poverty alleviation funds exert the maximum benefits, and truly achieve poverty alleviation and deliver genuine outcomes. Therefore, the development of rural inclusive finance can alleviate the multidimensional poverty of rural working-age population by improving the availability of financial products and services. However, the role of improving the quality of inclusive financial services and reducing the cost of services for poverty reduction has not yet been played, and the development of these two aspects should be further improved in the future. 
Table 10. Impact of each aspect of rural inclusive financial development on multidimensional poverty.

\begin{tabular}{|c|c|c|c|c|c|}
\hline & (1) & (2) & (3) & (4) & (5) \\
\hline ifi1 & $\begin{array}{c}-1.569 * \\
(0.801)\end{array}$ & & & & \\
\hline ifi2 & & $\begin{array}{c}-0.392 \text { ** } \\
(0.170)\end{array}$ & & & \\
\hline ifi3 & & & $\begin{array}{c}-0.970 * * \\
(0.378)\end{array}$ & & \\
\hline ifi4 & & & & $\begin{array}{l}-0.079 \\
(0.159)\end{array}$ & \\
\hline ifi5 & & & & & $\begin{array}{c}0.178 \\
(0.130)\end{array}$ \\
\hline$X_{i t}$ & $Y$ & Y & Y & Y & $\mathrm{Y}$ \\
\hline year & Y & Y & $Y$ & Y & Y \\
\hline province & $\mathrm{Y}$ & $\mathrm{Y}$ & $\mathrm{Y}$ & $\mathrm{Y}$ & $\mathrm{Y}$ \\
\hline _cons & $\begin{array}{c}2.324^{* * *} \\
(0.505)\end{array}$ & $\begin{array}{c}1.750 * * * \\
(0.284)\end{array}$ & $\begin{array}{c}1.761^{* * *} \\
(0.281)\end{array}$ & $\begin{array}{c}1.538^{* * *} \\
(0.287)\end{array}$ & $\begin{array}{c}1.453^{* * *} \\
(0.257)\end{array}$ \\
\hline$N$ & 15,590 & 15,590 & 15,590 & 15,590 & 15,590 \\
\hline r2_p & 0.106 & 0.106 & 0.106 & 0.106 & 0.106 \\
\hline
\end{tabular}

Note: The values in parentheses are standard deviations; ${ }^{*}, * * * * *$ indicate the level of significance of $10 \%, 5 \%$, and $1 \%$, respectively. Data is calculated by authors using Stata13.

\section{Conclusions and Suggestion}

Based on the evolutionary game model and empirical analysis, there are different poverty alleviation effects of inclusive financial development among the poor with different labor capacities. The development of China's rural inclusive finance can significantly alleviate the multidimensional poverty of rural working-age population, but this effect is not significant to the non-working-age population. Therefore, compared with the poor non-working-age population, if financial institutions provide loans to poor working-age population, they will achieve the dual goals of maintaining institutional sustainable development and alleviating poverty. In addition, the study also found that gender, age, marital status, household registration, family size and family burden ratio had significant effects on improving the multidimensional poverty of the rural population, and women are more likely to fall into multidimensional poverty than men, adults who are not married are more likely to fall into multidimensional poverty than those who are married, and the population with a rural household registration is more likely to fall into multidimensional poverty than those with a non-rural household registration, and the population with heavy family burden is more likely to fall into multidimensional poverty. Furthermore, the development of inclusive finance in aspects of permeability, usability, and utility can significantly reduce multidimensional poverty, but the development of inclusive finance in aspects of quality and affordability has not played its role on poverty alleviation.

Therefore, this article argues that in the game of poverty reduction, the stronger the labor capacity of the poor, the easier it is for the financial institutions and the poor to reach the equilibrium strategy of providing loans and applying for loans. So improving the financial availability of the working-age population is an effective way to fully realize the strategic goal of poverty alleviation in China. Furthermore, it even provides a new idea for poverty alleviation in the world. To further promote the development of rural inclusive finance, and guide rural inclusive finance to help target poverty alleviation, this paper puts forward the following policy suggestions. First, inclusive finance in poverty areas such as rural areas need to be developed, especially in remote and destitute rural areas. Second, rural areas, especially in the central and western regions, should speed up the development of the permeability, usability, and utility of inclusive finance. The quality and affordability of inclusive finance should be improved, especially in the east regions. Therefore, the eastern region should constantly innovate financial products and services, accelerate the development of internet finance and mobile finance, appropriately reduce transaction costs of financial services based on 
improving the quality of financial services, and effectively enable the poor to enjoy the benefits of inclusive financial development. The central and western regions should accelerate rural financial reforms, fully encourage and guide the policy-oriented financial institutions, commercial financial institutions, internet financial and mobile finance institutions to establish multi-level, wide-coverage, and sustainable rural inclusive financial systems in rural areas. Third, it is necessary to guide rural inclusive finance to give priority to serving the poor working-age population with the strongest ability to work and develop in rural areas, and constantly stimulate their endogenous motivation to lift themselves out of poverty through hard work, and improve their capacity for study and production. It is necessary to continuously improve the effectiveness and sustainability of alleviation effects of rural inclusive financial development on the multidimensional poverty of the rural working-age population.

Author Contributions: Writing—review \& editing, Y.Y.; Writing—original draft, C.F.

Funding: This research was funded by the National Social Science Foundation of China (no. 15ZDC027, no.18AJL002) and the research base of humanities and social science in Chinese Ministry of Education (no. 14JJD790042, no.16JJD790044).

Acknowledgments: We specifically used the China Family Panel Studies survey data which is available here: http:/ / www.isss.pku.edu.cn/cfps/.

Conflicts of Interest: The authors declare no conflict of interest.

\section{References}

1. Morduch, J. The microfinance promise. J. Econ. Lit. 1999, 37, 1569-1614. [CrossRef]

2. Ciani, M.; Gagliardi, F.; Riccarelli, S.; Betti, G. Fuzzy measures of multidimensional poverty in the Mediterranean Area: A focus on financial dimension. Sustainability 2019, 11, 143. [CrossRef]

3. Bihari, S.C. Financial inclusion for Indian scense. SCMS J. Indian Manag. 2011, 8, 7-18.

4. Corrado, G.; Corrado, L. Inclusive finance for inclusive growth and development. Curr. Opin. Environ. Sustain. 2017, 24, 19-23. [CrossRef]

5. He, D.; Miao, W. Financial exclusion, financial inclusion and inclusive financial institution in China. J. Financ. Trade Econ. 2015, 3, 5-16.

6. Zhou, G.; Gong, K.; Luo, S.; Xu, G. Inclusive finance, human capital and regional economic growth in China. Sustainability 2018, 10, 1194. [CrossRef]

7. Laborde, D.; Martin, W. Implications of the global growth slowdown for rural poverty. Agric. Econ. 2018, 49, 325-338. [CrossRef]

8. Kabeer, N. Is microfinance a 'magic bullet' for women's empowerment? Analysis of findings from South Asia. Econ. Political Wkly. 2005, 10, 4709-4718.

9. Park, C.Y.; Mercado, R. Financial Inclusion, Poverty, and Income Inequality in Developing Asia; Asian Development Bank Economics Working Paper Series; Asian Development Bank: Manila, Philippines, 2015.

10. He, X.; Kong, R. Mechanism analysis and empirical test of inclusive financial system alleviating rural poverty. J. Northwest AEF Univ. 2017, 3, 76-83.

11. Beck, T.; Demirgüç-Kunt, A.; Levine, R. Finance, inequality and the poor. J. Econ. Growth 2007, 12, 27-49. [CrossRef]

12. Su, J.; Liao, J. Empirical analysis of financial development, income distribution and poverty: Based on dynamic panel data. J. Financ. Econ. 2009, 12, 10-16.

13. Ding, Z.; Tan, L.; Zhao, J. The effect of rural financial development on poverty reduction. Issues Agric. Econ. 2011, 11, 72-77.

14. Cui, Y.; Sun, G. Is financial development the cause of poverty alleviation? Evidence from China. J. Financ. Res. 2012, 11, 116-127.

15. Chen, Y.; Zhang, D. County financial development and multidimensional poverty alleviation: Empirical research based on 51 poor counties in Hunan province. Theory Pract. Financ. Econ. 2018, 39, 109-114.

16. Leyshon, A.; Thrift, N. Geographies of Financial Exclusion: Financial Abandonment in Britain and the United States. Trans. Inst. Br. Geogr. 1995, 20, 312-341. [CrossRef] 
17. Kempson, H.; Whyley, C. Kept Out or Opted Out? Understanding and Combating Financial Exclusion; The Policy Press: Bristol, UK, 1999.

18. Liu, C.; Tian, L.; Chen, B.; Dai, K. Rural financial exclusion and urban-rural income gap-An empirical study based on Chinese provincial-level panel data model. J. Econ. Theory Bus. Manag. 2013, 10, 17-27.

19. Kondo, T.; Orbeta, A.; Dingcong, C.; Infantado, C. Impact of microfinance on rural households in the Philippines. IDS Bull. 2008, 39, 51-70. [CrossRef]

20. Khaki, A.R.; Sangmi, M.D. Does access to finance alleviate poverty? A case study of SGSY beneficiaries in Kashmir Valley. Int. J. Soc. Econ. 2017, 44, 1032-1045. [CrossRef]

21. Zhu, Y.; Wang, W. How does inclusive finance achieve precise poverty alleviation? J. Financ. Econ. 2017, 10, 43-54.

22. Kong, R.; Li, X. A Study on the credit game relationship between poor farmer and rural credit cooperatives based on trust: Shaanxi province as an example. J. Chongqing Univ. 2010, 16, 1-7.

23. Wang, H.; Wang, J. Farmer's credit behavior evolution based on evolutionary game model in financial linkage mode. J. Cap. Univ. Econ. Bus. 2019, 29, 42-49.

24. Sarma, M.; Pais, J. Financial inclusion and development. J. Int. Dev. 2011, 23, 613-628. [CrossRef]

25. Gupte, R.; Venkataramani, B.; Gupta, D. Computation of financial inclusion index for India. Procedia-Soc. Behav. Sci. 2012, 37, 133-149. [CrossRef]

26. Wang, X.; Guan, J. The income distribution effect and measure of rural financial inclusion in China. China Soft Sci. Mag. 2014, 8, 150-161.

27. Wu, X.; Xiao, X. Study on the financial inclusion index in a global perspective. J. South China Financ. 2014, 6, 15-20.

28. Chen, Y.; Sun, Q.; Xu, W. Dynamic and spatial convergent of distribution of Chian's inclusive finance development. J. Financ. Econ. 2015, 6, 72-81.

29. Guo, T.; Ding, X. International comparative study of inclusive finance-Based on the perspective of banking services. Stud. Int. Financ. 2015, 2, 55-64.

30. Li, T.; Xu, X.; Sun, S. Inclusive finance and economic growth. J. Financ. Res. 2016, 4, 1-16.

31. Luo, S.; Chen, X.; Yao, Y. Research on poverty reduction effect of inclusive financial development in China. J. Contemp. Econ. Res. 2016, 12, 84-93.

32. Zhang, H.; Luo, J.; Hao, Y. An analysis of the rural inclusive finance and its determinants: An empirical analysis based on data collected from 107 rural credit cooperatives in Shannxi province. J. China Rural Econ. 2017, 1, 2-15.

33. Wang, X.; Alkire, S. Multidimensional poverty measurement in China: Estimates and policy implications. J. Chin. Rural Econ. 2009, 12, 4-10.

34. Li, J. Measurement of multi-dimensional poverty among farmers: A case study of 30 key counties in S province for poverty alleviation and development. J. Financ. Trade Econ. 2010, 10, 63-68.

35. Zou, W.; Fang, Y. A study on the dynamic multidimensional measurement of China's poverty. Chin. J. Popul. Sci. 2011, 6, 49-59.

36. Alkire, S.; Santos, M.E. Measuring acute poverty in the developing world: Robustness and scope of the multidimensional poverty index. World Dev. 2014, 59, 251-274. [CrossRef]

37. Santos, M.E. Measuring Multidimensional Poverty in Latin America: Previous Experience and the Way Forward; OPHI Working Paper66; University of Oxford: Oxford, UK, 2014.

38. Alkire, S.; Seth, S. Multidimensional poverty reduction in India between 1999 and 2006: Where and how? World Dev. 2015, 72, 93-108. [CrossRef]

39. Zhang, Q.; Zhou, Q. Poverty measurement: Multidimensional approaches and an empirical application in China. China Soft Sci. Mag. 2015, 7, 29-41.

40. Guo, X.; Zhou, Q. Chronic multidimensional poverty, inequality and cause of poverty. Econ. Res. J. 2016, 6, 143-156.

41. Chen, L. Measurement and decomposition of multidimensional poverty in China during the transformation period. J. Econ. Rev. 2008, 5, 5-10.

42. Wang, C.; Ye, Q. Evolution on the multi-dimensional poverty of Chinese rural migrant workers. Econ. Res. J. 2014, 12, 159-174.

43. Gao, S.; Bi, J. Dynamic multidimensional poverty in rural China: Persistence and transition. J. China Popul. Resour. Environ. 2016, 2, 76-83. 
44. Bhalla, S. Inclusive growth? Focus on employment. Soc. Sci. 2007, 35, 24-43.

45. Alkire, S.; Foster, J. Counting and multidimensional poverty measurement. J. Public Econ. 2011, 95, 476-487. [CrossRef]

46. Alkire, S.; Foster, J. Understandings and misunderstandings of multidimensional poverty measurement. J. Econ. Inequal. 2011, 9, 289-314. [CrossRef]

47. Sarma, M. Measuring Financial Inclusion. Econ. Bull. 2015, 35, 604-611.

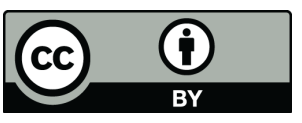

(c) 2019 by the authors. Licensee MDPI, Basel, Switzerland. This article is an open access article distributed under the terms and conditions of the Creative Commons Attribution (CC BY) license (http:/ / creativecommons.org/licenses/by/4.0/). 